\title{
Influential Factors of Innovation Input Decisions: Evidence of Chinese Listed Companies
}

\author{
Zhijun Lin ${ }^{1}$, Shijie Wang' ${ }^{2}$, Shizhong Yang2 ${ }^{*}$ \\ ${ }^{1}$ School of Business, Macao University of Science and Technology, Macao, China \\ ${ }^{2}$ Capital University of Economics and Business, Beijing, China \\ Email: *yangshiz@sina.com
}

How to cite this paper: Lin, Z. J., Wang, S. J., \& Yang, S. Z. (2021). Influential Factors of Innovation Input Decisions: Evidence of Chinese Listed Companies. American Journal of Industrial and Business Management, 11, 261-292.

https://doi.org/10.4236/ajibm.2021.113017

Received: December 9, 2020

Accepted: March 14, 2021

Published: March 17, 2021

Copyright $\odot 2021$ by author(s) and Scientific Research Publishing Inc. This work is licensed under the Creative Commons Attribution International License (CC BY 4.0).

http://creativecommons.org/licenses/by/4.0/

(c) (i) Open Access

\begin{abstract}
This study analyzes the influential factors underlying corporate innovation input decisions with a theoretical framework based on Cournot Equilibrium in game theory. By identifying the influential factors in theoretical deduction, we incorporate these factors with a sample of Chinese listed companies to empirically examine their impact on corporate innovation input decisions (e.g., R\&D investment). The results reveal that corporate innovation input in terms of R \& D investment is negatively associated with innovation risk, product cost and cost of capital, and positively related to profitability and innovation efficacy, which are consistent with the inferences of the theoretical framework and confirm the validity of our analytical model. With expanded sample range (multi-industries) and incorporation of market and governmental factors simultaneously, the findings are confirmatory to the main views of previous studies, and help to clarify the inconsistency in the findings in the extant literature. However, our empirical findings show that the type of business ownership (nature of equity right) and the level of regional marketization development do not significantly affect corporate $R \& D$ investment by the sample Chinese listed companies at present. This may be an evidence to support the development status of a market economy in China.
\end{abstract}

\section{Keywords}

Corporate Innovation, Innovation Input Decisions, Cournot Equilibrium, Government Subsidies, R\&D Investment, Chinese Economy

\section{Introduction}

Innovation is the first driving force behind technological competition, and busi${ }^{*}$ Corresponding author. 
ness enterprises are major innovation carriers at the micro-level. For instance, 77.4\% of scientific research funding in China came from business sector in 2018. In the first half of 2019, the total R\&D investments of A-share listed companies reached RMB 313.9 billion ( $\mathrm{RMB} 6.50=1$ US dollar). Nowadays, innovation becomes the most crucial productive force for the development at both macroand micro-levels. All countries in the world have made great effort to stimulate innovation and development (Blundell et al., 2010; Diéguez-Soto et al., 2016; Hong et al., 2016; Jabeen et al., 2019). An adequate understanding of corporate innovation process and decision making mechanism is of great significance to promoting innovation and improving the growth potential of business enterprises through innovation efforts.

The input for innovation, normally the $\mathrm{R} \& \mathrm{D}$ investment or spending, is the key of innovation success as business enterprises are the major entities engaging in innovative activities. How to make most efficient and effective innovation input is one of the most critical strategic decisions by business enterprises and this has attracted great attention of academics and professionals (Audretsch, 1988; Mairesse \& Mohnen, 2002; Antonelli, 2006; Blundell et al., 2010; Chen \& Lin, 2019). Many studies have focused on the decision-making process and the influencing factors to corporate innovation input decisions in order to determine the driving cause and effectiveness of innovation inputs, including the development of different analytical models to take quantitative analysis (Mohanty et al., 2005; Hauschild \& Reimsbach, 2015; Kim et al., 2014; Kock \& Gemunden, 2016). However, most of the existing analytical models for innovation investment decision-making are too complicated to apply and could not be adopted in business management practices. In addition, prior research on the influential factors underlying corporate innovative activities is lack of generally-accepted theoretical framework, and the conclusions obtained in the extant literature are varied, or even contradictory (Mairesse \& Mohnen, 2002; Lee, 2005). This warrants further theoretical and empirical analysis of corporate innovation decisions.

Innovation input such as the selection of $\mathrm{R} \& \mathrm{D}$ investment projects is a complex decision-making process (Mohanty et al., 2005; Barasa et al., 2019). Based on the Cournot Equilibrium in game theory, this study constructs a theoretical framework of decision-making for innovation input by business enterprises, and analyzes the influential factors underlying corporate innovation input (e.g., R\&D investment) decision making with an empirical test. Additional to firm-specific characteristics, the market and government factors are taken into consideration simultaneously to identify their influence or joint effects. The main variables of interest include those having been adopted in earlier studies on corporate innovation input decisions. To alleviate the potential missing variable problem, we expand the study sample from manufacturing sector to other industrial categories, including transportation, tele-communication, hotel and catering, wholesales and retails, construction and real estate, to ensure the study results can have a broad representation and more general implications. The empirical re- 
sults, in the content of Chinese capital market, are, in general, consistent with the main findings of prior research. The validity and applicability of the theoretical framework on corporate innovation input decision-making are therefore confirmed by the empirical results.

It is also noted that the nature of equity ownership (i.e., types of enterprise property rights) and the level of regional marketization development do not have a significant impact on the innovation input ( $\&$ D investment) decisions by Chinese business enterprises at present, which deviates from that of earlier studies. We infer that the effect of these two factors is diminishing due to the advancement of marketization in China. In particular, the deepening reforms for the state-owned enterprises (SOEs) have transformed them into market participants. The Chinese government has substantially reduced administrative regulation and intervention over business decision-making and enables the market to play regulatory roles. With the mature of market operation nationwide, business entities with varied types of equity ownership and geographical locations are under similar market pressure for innovation and competition. There is no more centralized planning or direct intervention of business innovation input decisions. All business enterprises should take innovation activities with R\&D investment to sustain growth. In this regard, it may also be a supporting evidence to indicate the establishment of market economy status in China.

\section{Study Background}

Many studies have examined the necessity and benefits of business innovation (Schumpeter, 1951; Audretsch, 1988; Diéguez-Soto et al., 2016; Crowley \& Bourke, 2018; Jabeen et al., 2019), while a wide research interest is on the input and output of innovative activities, in particular, the investment on innovation ( $R \& D$ investment) and the influencing factors underlying innovation input decisions (Lee, 2005; Carlsson et al., 2007; Cai et al., 2013; Chang et al., 2016; Crowley \& Bourke, 2018). Although innovation is the most crucial strategic objective, the decision on innovation input is relatively difficulty to made due to a great uncertainty in the expected innovation output, i.e., the physical outcomes and the commercial value of innovation output are not only unpredictable but also possible of a complete failure (Mairesse \& Mohnen, 2002; Aghion et al., 2005). Thus many previous studies have developed different analytical models to explain the decision making process and the influencing factors for corporate innovation input (R\&D investments) decisions (Almus \& Czarnitzki, 2003; Mohanty et al., 2005; Antonelli, 2006; Blundell et al., 2010; Park, 2015; Barasa et al., 2019).

Extant research results on innovation input decisions are abundant but few has gained general acceptance. In particular, prior research has analyzed innovation input decisions mainly in the respect of firm-specific characteristics in constructing analytical models, while the externality factors are either examined separately or neglected, unable to yield a comprehensive explanation for corpo- 
rate innovation input decision making. Moreover, the theoretical analyses in prior research could not directly match with innovative practices in the real business world, while most theoretical models are not validated with convincing empirical findings.

\subsection{Research on Innovation Input Decisions}

Basic characteristics of innovation activities include that innovation projects are future-oriented and cross-periods with opportunity cost consideration. The trade-off effect should be taken into consideration in the evaluation and selection of innovation investment projects (Mairesse \& Mohnen, 2002; Mohanty et al., 2005; Kock \& Genumden, 2016). Therefore, Baker et al. (2011) introduced the real option model into the selection decision of $R \& D$ investment that faces uncertainty and risk in the consequent output, which has attracted great attention in research (Ho et al., 2011; Denison et al., 2012; Hauschild \& Reimsback, 2015; Chang et al., 2016; Kim et al., 2020). In China, Li and Zen (2009) apply the real option modeling method to examine the influence of financing capability on corporate innovation investment decisions. They report that, in a market with uncertainty, business enterprises reduce their investments in innovation projects, and when there is a technological uncertainty, enterprises would undertake innovation investment to break through technological constraints. However, financing capability will impact the scale of innovation investment. Wang and Zhao (2010) also analyze the multi-stage corporate R\&D investment decisions. They find that project risk, expected returns, opportunity cost and other factors are correlated, i.e., opportunity cost, investment cost, and option value of investment opportunity are positively correlated, which may affect corporate R\&D investment enthusiasm. In addition, Zhao (2014) applies the principles of real options modeling to evaluate the impact of sales volume and price changes on firms' decisions for the breakthrough innovation projects and report that there is a positive association.

Hauschild \& Reimsbach (2015) contend that the existing real option models for determining optimal investment strategy may lead to a negative impact on the allocation of innovation resources, and propose a heuristic binomial method to establish a R\&D investment model in a sequential order. Gu (2015) adopts the real options theory to analyze the influences of cash flow changes, external risks, investment scale and other factors on the choice of innovation projects by business management, and build a multi-stage $R \& D$ project selection decision-making model. Nonetheless the models derived from the real option theory are difficult to establish a direct relationship between the influencing factors and corporate innovation investments because of their complicated calculations (Baker et al., 2011). Some studies have shown that the complexity and the lack of theoretical justification hinder the applicability of the real option models, so this method has not been generally adopted in corporate innovation input decision-making in practice (Villani, 2014; Chang et al., 2016). 
Fuzzy mathematics has also been used in the analysis of decision-making on innovation investment (Dhingra \& Moskowitz, 1991). Zhang et al. (2007) adopt the fuzzy theory to evaluate corporate technological innovation upon multiple objectives, and analyze the evaluation process with multiple objectives such as cost, functional efficacy, reliability, and product life. Li et al. (2011) utilize multi-attribute fuzzy modeling in decision-making to evaluate the attributes of process innovation by manufacturing enterprises, such as innovation output, product cost, and quality improvement with evidence in China. Yang and Yu (2018) further apply the intuitionistic fuzzy multi-attributes of decision-making method to assess the determining factors such as profit and cost in innovation input decisions. The innovation decision-making models based on fuzzy mathematics can compare the pros and cons of alternative innovation projects through examining relevant influential factors, however, they could not directly evaluate the efficacy of innovation projects (Garg \& Kumar, 2018).

In addition, Yuan and Yang (2010) apply systematic dynamics analysis method and find that the innovation performance of privately-run enterprises is affected by three types of factors: entrepreneurs, market, and government. These factors interact with, and affect corporate innovation through information feedback. Sun et al. (2017) develop a two-stage model to analyze the impact of governmental subsidies on corporate innovation activities and contend that government subsidies have a greater stimulating effect on innovation inputs (e.g., R\&D investment) by non-state-owned enterprises. Lu and Wang (2019) adopt the famous Cobb Douglas Production Function to study the impact of labor and capital mismatch on innovation inputs by Chinese listed manufacturing companies, and report that mismatch of labor resource significantly prompts corporate innovation, and the factors such as firm size may also affect corporate innovation activities. Chen and Lin (2019) adopt game theory approach with added constraints to construct the production output and product pricing decision models under varied innovation strategies, and use the financial data of the listed automobile companies to verify the discerning capability to identify corporate competitive strategies undertaken by the sample companies. Their study validates the relevant Porter's Hypotheses that an appropriate governance environment motivates technological innovation, and identifies the theoretical association of the impact of innovation input on the output and price of different products under varied competitive strategies. But they merely explain the decision-making process and the optimal solution of corporate innovation input decisions.

Noted that different theories and analytical methods are adopted in prior research to examine corporate innovation input decision making and extract relevant influential factors with various explanations. Overall, the theoretical or analytical models for innovation input decisions constructed by taking the real option theory are complicated in calculation, difficult to interpret explicitly, thus, it is rarely used in the decision-making process for corporate innovation 
projects in the real business world. Analytical models derived from Fuzzy mathematical method help to evaluate and identify the optimal solution for different innovation input projects, but they could still not be conveniently used in corporate innovation decision-making.

Recently, some Chinese scholars have developed varied models to analyze the impact of government subsidies, resource mismatches, and competitive strategies on corporate innovation investment from different perspectives (Sun et al., 2017; Chen \& Lin, 2019). According to Lu and Wang (2019), the interaction effect of different factors should have an impact on corporate innovation investment decisions. However, the earlier research focuses mainly on certain influential factors, which is with a missing variable problem. It is difficult to fully explain the magnitude of influence of different factors underlying corporate innovation input decision-making process, and may lead to inconsistent conclusions.

\subsection{Influential Factors of Innovation Inputs}

Previous studies on corporate innovation decision-making have focused on factors from three perspectives: the enterprise, the market and the government, but their findings are not consistent.

\subsubsection{Firm Perspective}

Schumpeter (1951), the Master of contemporary management science believes that firm size is a critical determining factor for business innovation, and large companies are more innovative. However, later studies have yielded inconsistent conclusions (Audretsch, 1988). In terms of publicly-listed companies, for manufacturing industry in particular, empirical evidence shows that $R \& D$ investment is negatively correlated with the size of company, while the data of small and medium-size listed companies demonstrate that they are positively correlated (Jabeen et al., 2019). In China, Ren et al. (2010) show that firm size is positively correlated with total investment in which R\&D investment (innovation input) accounts for a substantial part. Zhang and Zhong (2014) have however revealed that firm size and corporate innovation investment are of a positive U-shaped relationship.

Profitability is another firm-specific influential factor (Crowley \& Burke, 2018). Business profits are the ultimate source of corporate innovation input. High profitability can generate more resources for innovation activities (Mairesse \& Mohnen, 2002), although a few studies show that the impact of profitability is not significant (Diéguez-Soto et al., 2016). In China, some studies with sample from high-tech industries and emerging strategical industries show that corporate profitability is positively associated with innovation activities, but such an impact is insignificant for manufacturing industries (Luo \& Liu, 2009; Sun et al., 2017).

Debt ratio determines financial risks and the cost of capital of an enterprise and will affect the cost of corporate innovation inputs. For example, Cai et al. (2013) report that an increasing debt ratio promotes innovation investment by enterprises in chemical industry, but evidence from strategically emerging in- 
dustries shows that a high debt ratio handicaps corporate innovation investment (Fu et al., 2016).

Age of business enterprise is also a frequently-cited influential factor (Blundell et al., 2010). A company with a longer life span is more familiar with the industrial environment, which helps to reduce innovation risks and will promote its innovation efforts. Yuan and Yang (2010) hold this view on their study of the Chinese listed manufacturing companies. However, there is an opposite view in other studies (Shen \& Zou, 2018).

Cheng and Dai (2012) argue that varied modes and scope of government intervention for business enterprises combining with different types of properties right (e.g., equity ownership) will impact corporate innovation behaviors. In China, a few studies have shown that both the innovation input and innovation output of the state-owned enterprises (SOEs) are higher than that of privately-run enterprises and other Non-SOEs (Wu, 2012). On the contrary, Yuan and Yang (2010) contend that both innovation input and output are insufficient in SOEs. Research findings with the sample of Chinese listed companies are generally consistent that SOEs are less innovative in comparison to the non-SOE counterparts (Luo \& Liu, 2009; Zhang \& Zhong, 2014; Fu et al., 2016).

\subsubsection{Market Perspective}

Business enterprises gain economic benefits through market competition, and market competition will surely affect corporate innovation behaviors. Schumpeter (1951) posits that there is a positive relationship between monopoly and innovation, high market concentration (monopoly) means weak competition, and most business enterprises have to continuously innovate to enhance their market advantage and competitive power. Nonetheless, the opposite view argues that the higher the market concentration, the greater the market advantages of dominating enterprises, so the smaller the incentive for them to innovate, and the less the effort or input of innovation (Chen \& Yu, 2007; Turner et al., 2010; Diéguez-Soto et al., 2016). There is also a view of inverse U-shaped relationship between market concentration and corporate innovation (Aghion et al., 2005; Crowley \& Bourke, 2018). In China, Wang (2015) argues that low industrial concentration is beneficial to the innovation by business enterprises, while Gao et al. (2017) provide evidence to support the inverse U-shaped relationship between market concentration and corporate innovation efforts.

Cheng and Dai (2012) report industrial characteristics have an impact on innovation behaviors of the participants in segmented market, and it is generally believed that the capital intensity (e.g., for capital intensive industry or firms) is positively correlated to innovation input. However, Wang et al. (2017a), Nakil, (2014) present that capital intensity is negatively correlated with innovation output for the high-tech listed companies in China.

\subsubsection{Government Perspective}

Governmental control or economic regulation at the macro-level should affect 
corporate behaviors (Almus \& Czarnitzki, 2003; Grossi et al., 2015). In China, with the unification of tax systems across the country in the early 2010s, it becomes difficult for local governments to prompt corporate innovation investment through offering preferential tax incentives or treatments, and the improvement of local institutional environment has become the main means of governmental regulation (Cheng \& Dai, 2012; Sun et al., 2017). Earlier studies generally use the level of marketization development to proxy for the scope of local government regulation, and it is generally believed that the development level of regional marketization is significantly and positively correlated with corporate innovation efforts ( $\mathrm{Li}$ et al., 2011), such a view is supported by the findings in earlier studies for Chinese manufacturing companies (Zhang et al., 2007; Fan et al., 2011; Wang et al., 2017a).

In addition, governments (both central or local) will provide direct inputs to induce or encourage business enterprises to undertake innovation activities. Governmental subsidy to innovation inputs (e.g., R\&D investment) is a direct means of government intervention and helps reduce corporate risks for undertaking innovation activities, so it is generally believed that governmental subsidies are positively associated with corporate innovation investment ( $\mathrm{Wu}, 2012)$, which is also supported by some other studies (Shen \& Zou, 2018).

\subsection{Summary of Literature Review}

Prior research has generally agreed that corporate innovation input decisions are driven by certain influencing factors, such as firm age, governmental subsidies, regional marketization development, and the nature of equity ownership but inconsistent findings are reported on the effect of other factors (Lee, 2005; Antonelli, 2006; Turner et al., 2010; Cai et al., 2013; Zhang \& Zhong, 2014; Barasa et al., 2019). The lack of research on the theoretical framework and mechanism of corporate innovation input decision making makes the empirical results inconsistent or inconvincible (Antonelli, 2006; Tan et al., 2018; Yu et al., 2019). As aforementioned, the analyses based on structured models derived from various theories focus mainly on certain factors individually or separately and are difficult to reflect the simultaneous effects of multiple factors. Due to the variation in the selection of multi-dimensional descriptive variables to develop analytical modeling, varied study findings appear in previous studies due to inappropriate data selection, inadequate measurement and other reasons, and they have not yielded conclusions with sufficient explanatory power (Hauschild \& Reimsbach, 2015; Chen \& Lin, 2019). Most existing mathematical models for studying corporate innovation input decisions are either too complicated in modeling or lack of theoretical justification, and are unable to directly explain corporate innovation practices, resulting in the difficulty of modeling application. In addition, the prior research on the influential factors of corporate innovation input decisions adopting multiple regression methods has focused only on a few factors and analyzed the effect of major variables, while less attention has been paid to the 
control variables such as market- and governmental characteristics. This is suffered from the drawback of missing variable problem, which yields inconsistent conclusions.

In particular, there is insufficient attention to the roles of the two regulatory means at the macro-level; the government and the market. A few studies have examined the impact of government or market factors on corporate innovation behaviors alone, but they have not analyzed the integrated effect of the two types of external influential factors along with firm-specific factors, so their findings may not be sufficiently robust. In addition, the samples in relevant prior research in China are targeting only at manufacturing industry and high-tech industry. Study samples drawn from different geographical regions and industries alone have aggravated the inconsistent findings caused by the selection of different variables and research methods. Therefore, this study attends to develop an integrated theoretical framework to analyze the impact of various influential factors on corporate innovation input decisions simultaneously, especially incorporating the government and market factors. Furthermore, we use a sample of the Chinese listed companies to empirically examine the validity and applicability of the theoretical framework for corporate innovation input decision making in the respect of corporate $\mathrm{R} \& \mathrm{D}$ investment in the context of Chinese economy.

\section{Theoretical Framework for Corporate Innovation Input Decisions}

The Cournot oligopoly equilibrium is a classic market-based game theory modelling (Amir, 1996; Campos et al., 2005). When the number of participating enterprises increases continuously, in terms of the Cournot Equilibrium, the market will approach perfect competition, even with incomplete information (Müller, 2006; Crespi et al., 2017). According to Porter's Generic Strategy Theory, companies achieve profit maximization through the strategies of either cost leader or product differentiation in business operation (Roger, 1996). When market conditions remain unchanged, cost-leader companies (with lower product cost) can obtain higher profits; or product-differentiation companies can build up monopoly or find new market segment to earn high profits (Allen \& Helms, 2006). Innovation of production process helps reduce product costs, achieving cost leadership, realizing the efficacy of innovation, and improving firm production efficiency and effectiveness. On the other hand, product differentiation through innovation assists firms to develop new products and achieve differentiation advantage, yielding a substitution effect of innovation. When new products occupy the market, some enterprises producing old products will be expelled from the market (Markides \& Geroski, 2004). Thus innovation enables business enterprises to maximize profitability through competition with lower production costs or new products.

It is assumed in the Cournot game theory that products are homogeneous, 
and price is determined by the market, producing enterprises determine their output through a game process to maximize their profits. Products in the same market segment are generally homogeneous, thus the Cournot Equilibrium can interpret the cost-reduction effect of corporate innovation in production process. At the same time, product innovation strategy helps explore new market segments, so innovative companies in respect of developing new products obtain higher profits through monopoly or oligopoly, which can also be explained by the Cournot game model.

At present, most market segments in China have a high level of homogeneity, and product prices are mainly determined by the market. Companies have to reduce costs or refine segmented markets through initiating innovation activities to maximize their profits. Therefore, we intend to examine the impact of corporate innovation input decisions on corporate profitability in light of the Cournot game theory.

Let's assume that products in a market segment are homogeneous and there are $n$ participating enterprises, the production cost of enterprise $i$ is denoted $c_{p}$ its production output is $q_{p}$ total production output in the market is $Q$, and the price $P$ is set by the market. The inverse demand function of the market can be represented as:

$$
P=\alpha-\beta Q
$$

Let $Q-q_{i}=Q_{-i}$, then the marginal revenue function of firm $i$ is:

$$
M R_{i}=\alpha-\beta Q_{-i}-2 \beta q_{i}
$$

A firm's profit $\Pi_{i}$ depends upon the market price $P$, its sales $q_{i}$ and cost $c_{i}$. The realization condition of profit maximization is that of the marginal revenue equals the marginal cost:

$$
\alpha-\beta Q_{-i}-2 \beta q_{i}=c_{i}
$$

To solve Equation (3), the available market equilibrium price $P$ and the maximized profit $\Pi_{i}$ are as:

$$
\begin{gathered}
P^{*}=\frac{\alpha+\sum_{i=1}^{n} c_{i}}{n+1} \\
\Pi_{i}\left(P, q_{i}, c_{i}\right)=\left(P-c_{i}\right) q_{i}=\left(P-c_{i}\right) \frac{P-c_{i}}{\beta}=\frac{\left(P-c_{i}\right)^{2}}{\beta}
\end{gathered}
$$

Thus an enterprise can maximize its profit by reducing product costs $c_{\vec{r}}$ Assuming that the cost of an innovative enterprise (undertaking innovation) is reduced and the total market demand curve remains unchanged, the consequences of the enterprise in playing game with other enterprises in the market are as the Scenarios 2-7 shown in Figure 1. Judging from the perspective of business profitability, any enterprise's innovation to reduce costs will increase its own profits, while lowering market price will reduce the profits of other enterprises in the market. In Scenario 8, none of the enterprises taking innovation and they maintain the status quo in the market. However, some business enterprises should try 

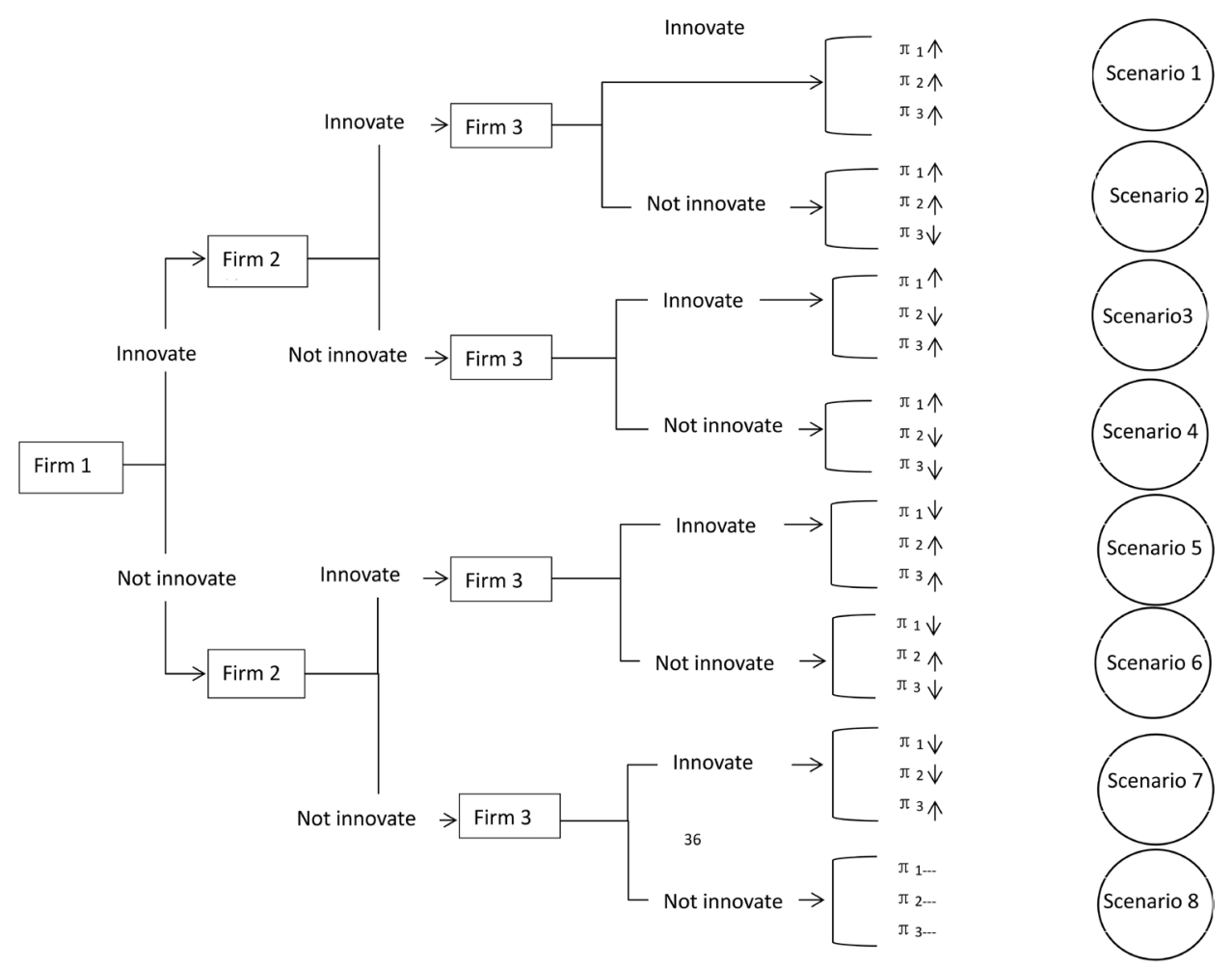

Figure 1. Decision tree and consequences of corporate innovation game.

to pursue innovation for their own interests, so the optimal solution is exhibited as Scenario 1. In other words, all participating enterprises have to undertake innovation activities to maintain or maximize their profitability.

The aforementioned corporate game in the market does not consider the uncertainty of innovation. However, whether an innovation is successful and how its efficacy will affect innovation behavior are involved with great uncertainties. According to Denison et al. (2012), the outcome of innovation efforts may be unpredictable, deferred across periods, and may fail to achieve the expected benefit. The success of innovation depends upon how to control for risk and investment (input). Innovation risk is represented by $\theta_{i}>0$. The larger $\theta_{i}$, the greater risk of innovation. Assuming the innovation input (e.g., R\&D investment) is represented by $x_{i}$, the larger the $x_{p}$ the higher the chance of innovation success. Therefore, the success rate of corporate innovation effort (input) can be defined as below:

$$
\varphi\left(X_{i}\right)=\frac{x_{i}}{x_{i}+\theta_{i}}
$$

Further assuming that the innovation efficacy is $\mu_{p} 0<\mu_{i}<1$, the product cost changes from $c_{i}$ to $\left(1-\mu_{i}\right) c_{i}$ when the innovation is successful. The larger the $\mu_{p}$ the better the innovation outcome. The innovation efficacy $\mu_{i}$ is therefore jointly affected by the substance of innovation, product characteristics, and operational process.

Ignoring the time factor, $\Pi_{i}^{0}$ and $\Pi_{i}^{1}$ represent the profits of enterprise $i$ 
before- and after a successful innovation, and the profit increment brought in by the successful innovation is denoted as $d_{i}$ :

$$
\begin{aligned}
d_{i} & =\Pi_{i}^{1}-\Pi_{i}^{0}=\frac{\left(p^{1}-c_{i}^{1}\right)^{2}}{\beta}-\frac{\left(p^{0}-c_{i}\right)^{2}}{\beta} \\
& =\frac{1}{\beta}\left[\left(P^{1}-\left(1-\mu_{i}\right) c_{i}\right)^{2}-\left(P^{0}-c_{i}\right)^{2}\right]>0
\end{aligned}
$$

Among them, $c_{i}$ and $c_{i}^{1}$ represent respectively the production cost beforeand after the innovation effort is successful, $P^{0}$ and $P^{l}$ denote the market equilibrium price before- and after the successful innovation: $P^{0}=P^{l}=P$. Then the expected profit increment derives from corporate innovation activities is as $\Delta \Pi_{i}$.

$$
\Delta \Pi_{i}=\varphi(x) d_{i}-x_{i}=\frac{d_{i} x_{i}}{x_{i}+\theta_{i}}-x_{i}
$$

A critical decision-making for corporate innovation is then to determine the innovation input $x_{i}$ that can maximize the expected profit increment. When Formula (8) is equal to 0 , then $X_{i}$ is:

$$
x_{i}=d_{i}-\theta_{i} \text { or } 0
$$

Taking the derivation of $x_{i}$ in Equation (8)

$$
\frac{\partial \Delta \Pi_{i}}{\partial x_{i}}=\frac{d_{i} \theta_{i}}{\left(x_{i}+\theta_{i}\right)^{2}}-1
$$

Let the derivative equals to 0 , then:

$$
x_{i}=\sqrt{d_{i} \theta_{i}}-\theta_{i}=\sqrt{\frac{1}{\beta}\left[\left(P^{*}-\left(1-\mu_{i}\right) c_{i}\right)^{2}-\left(P^{*}-c_{i}\right)^{2}\right] \theta_{i}}-\theta_{i}
$$

When $d_{i}>\theta_{i}, \quad d_{i}-\theta_{i}>\sqrt{d_{i} \theta_{i}}-\theta_{i}>0$, then $x_{i}$ is in the interval of $\left(0, \sqrt{d_{i} \theta_{i}}-\theta_{i}\right)$, the solution of Formula (8) is greater than 0 , and $\Delta \Pi_{i}$ is an increase function of $x_{i}$. When $x_{i}$ is in the interval of $\left(\sqrt{d_{i} \theta_{i}}-\theta_{i}, d_{i}-\theta_{i}\right)$, Formula (8) is smaller than 0 , and $\Delta \Pi_{i}$ is a decreasing function of $x_{i}$. In the interval of $\left(0, d_{i}-\theta_{i}\right), \Delta \Pi_{i}$ is greater than 0 , so the relationship between $\Pi_{i}$ and $X_{i}$ is inversely $\mathrm{U}$-shaped. As indicated in Formula (11), $\Delta \Pi$ will be the largest, i.e., an enterprise can reach the largest profitability after taking innovation activities (i.e., cost reduction or product differentiation):

$$
\Delta \Pi_{i}=\left(\sqrt{d_{i}}-\sqrt{\theta_{i}}\right)^{2}=\left(\sqrt{\frac{1}{\beta}\left[\left(P^{*}-\left(1-\mu_{i}\right) c_{i}\right)^{2}-\left(P^{*}-c_{i}\right)^{2}\right]}-\sqrt{\theta_{i}}\right)^{2}
$$

If a firm invests in innovation projects in terms of its capital constraint interval $\left(0, \sqrt{d_{i} \theta_{i}}-\theta_{i}\right)$, when the innovation investment is beyond the upper limit of $\left(\sqrt{d_{i} \theta_{i}}-\theta_{i}\right)$, its profitability brought by the innovation effort will however be reduced. When $d_{i}<\theta_{i}, d_{i}-\theta_{i}<\sqrt{d_{i} \theta_{i}}-\theta_{i}<0$, and when $\Delta \Pi_{i}$ is the largest, the value of $x_{i}$ should remain $\sqrt{d_{i} \theta_{i}}-\theta_{i}$. At this time, $x_{i}$ is smaller than 0 , but it has no practical significance. The theoretical significance is that if all incremen- 
tal profits derived from successful innovation input $d_{i}$ to be reinvested in innovation cannot guarantee a success rate is higher than $50 \%$, then the innovation activities are undesirable. ${ }^{1}$

Therefore, whether or not should an enterprise take innovation and how much should it invest in innovation projects depend upon the success rate of the innovation, innovation efficacy and market demands. Specifically, the demand curve slope $\beta$, market price $P$, product $\operatorname{cost} c_{p}$ innovation efficacy $\mu_{p}$ and innovation risk $\theta_{i}$ should all impact a firm's innovation decisions, $\beta, P, c_{i}$ and $\mu_{i}$ jointly determine the incremental profit $d_{i}$. In light of Formula (11) and the value range of $x_{i}$ the optimal innovation input $x_{i}$ is positively associated to $d_{i}$ negatively related to $\beta$, positively related to $P$, negatively related to $c_{p}$ positively related to $\mu_{p}$ and negatively related to $\theta_{i}{ }^{2}$

Taking the time factor into consideration, investment in innovation projects and the economic consequence are of cross-periods. So it is necessary to consider the incremental net present value brought about by innovation projects, but the above inference is still valid. When the success rate of investment in innovation to generate incremental benefits (incremental net present value) is greater than $50 \%$, the investment should be undertaken, otherwise no innovative projects should be carried out. When taking innovation activities, the time value of cost of capital should affect the incremental net present value of the innovation project. Under the same conditions, the lower the cost of capital, the greater the incremental net present value generated by innovation. Therefore, it is contended that the cost of capital is negatively related to innovation input decision.

In short, corporate input on innovation activities (e.g., R\&D investment) is negatively associated with innovation risk, product cost and cost of capital, and positively related to innovation efficacy and product price, as well as change in market demand. This is our analytical framework of the influential factors on corporate innovation input decisions in light of the Cournot game theory. We then select a sample of Chinese listed companies to empirically examine the validity and applicability of the theoretical framework in respect of corporate innovation input decision making (e.g., $R \& D$ investment), and make comparison with the findings of earlier studies.

${ }^{1}$ According to formula (11), $\quad c_{i} \in\left(\frac{p}{2-\mu}-\delta, \frac{p}{2-\mu}+\delta\right)$, as $\delta=\sqrt{\left(\frac{p}{2-\mu}\right)^{2}-\frac{\beta \theta}{2 \mu-\mu^{2}}}$. When $c_{i}<P /(2-\mu)$ is positively correlated with innovation input (R\&D investment) $x_{i}$, if $c_{i}>P /(2-\mu)$, it is negatively correlated with innovation input $x_{i^{*}}$. Considering that $\mu$ is generally small in real business practice, and product cost usually accounts for more than half of the price, so product cost $c_{i}$ is negatively correlated with $x_{i}$.

${ }^{2}$ In terms of Formula (11), the optimal innovation input $x_{i}$ and $\theta_{i}$ have an inverted U-shaped relationship: $\theta_{\mathrm{i}}$ is in the interval $\left(0, d_{i} / 4\right), x_{i}$ is an increasing function of $\theta_{i} \cdot \theta_{i}$ is in the interval of $\left(d_{i} / 4\right.$, $+\infty)$, and $x_{i}$ is the decreasing function of $\theta_{i}$. If $\theta_{i}$ is less than $d_{i} / 4$, it means that the innovation risk is small and the expected incremental benefit is high. In the real business practice, there is few opportunity for such an innovation efficacy, and more common is in the interval $\left(d_{i} / 4,+\infty\right)$, and $x_{i}$ is a decreasing function of $\theta_{i}$. This is consistent with the reality that companies are more willing to invest in innovative projects with less difficulty and low risks. 


\section{Hypotheses and Analysis Models}

\subsection{Hypotheses}

In light of the theoretical framework for corporate innovation input decision making based on Cournot game theory, we posit that corporate innovation input decisions are jointly affected by factors from multiple perspectives, including enterprise, government and market, all should be considered simultaneously.

\subsubsection{Firm Characteristics}

Larger size business enterprises produce more products, and they need to take more innovation activities to sustain their growth (Ren et al., 2010). The scale effect helps reduce production costs and promote the successful rate of innovation input (R\&D investment). Therefore, we set the first hypothesis in light of enterprise-specific characteristics as below:

$H 1$ a: Firm size is positively correlated with corporate innovation input ( $R \& D$ investment).

Judging from the analytical framework based on Cournot game theory, if a company has a high profitability, it should have more obvious advantages in product cost or price. The lower the unit product cost; or the higher the product price, the greater the profit margin. A greater profitability can generate more low-cost internal funds to reduce the cost of capital to finance innovation projects, therefore a business enterprise is more willing to increase innovation input (R\&D investment) to obtain competitive advantage. The second hypothesis can be set as:

$H 1 b$ : The profitability of a listed company is positively correlated with its innovation input ( $R \& D$ investment).

According to the theory of financial constraint, the optimal financial leverage is a relative term, when debt ratio is within a rational range, a firm could reach an optimal capital structure (Hart, 1996). In the past, the listed companies in China had a preference for equity financing (Luo \& Liu, 2009). But the increasingly stringent capital market surveillance has made it more difficult for listed companies to refinance in the equity market. Debt financing has become an important channel of corporate financing at present. Debt financing may ease the budget constraints of corporate innovation input. Thus we assume that the higher the debt ratio, the more the investment in innovation projects.

Hl c. Debt ratio of a listed company is positively correlated with its innovation input ( $R \& D$ investment).

Firm age is important for innovation investment based on the life cycle of business operation (Peltoniemi, 2011). The older the company is, the more familiar it is with the industry, so the company will face lower risk of innovative effort and have higher chance of innovation success, which may lead to an increase in its innovation investment, i.e.:

Hl d: Age of a listed company is positively correlated with its innovation input ( $R \& D$ investment). 
It is generally believed that SOEs are under government protection or patronage, so they have less motivation for innovation efforts (Watanabe, 2002; Li \& Song, 2010; Grossi et al., 2015). Nonetheless, some recent studies in China report that, although SOEs shoulder additional social responsibilities as requested by governments, they are still profit-oriented business entities as profit maximization should remain the major operational priority. Therefore, we posit the decisions on innovation input (R\&D investment) should not be affected by the nature of equity ownership (type of enterprise property rights), particularly in a market economy. At the same time, in pace with the rapid progress of capital market in China, the substantial improvement of governance structure of listed companies and the extended SOEs reforms to push them toward direct market competition, the Chinese government authorities have substantially reduced direct intervention over the production and operation of SOEs (Sun \& Li, 2014; Sun et al., 2017; Graaff et al., 2020). We therefore contend that the nature of equity ownership (type of property rights) may no longer be a determinant for corporate innovation investment in the current market-oriented economy in China, which leads to the hypothesis as below:

$H 1 f$. The nature of the equity ownership of a listed company has no significant impact on its innovation input ( $R \& D$ investment).

\subsubsection{Market Characteristics}

Market characteristic factors will directly affect business operation and corporate behavior, such as the degree of market competition and the characteristics of market segmentation (Lee, 2005; Liang et al., 2004; Bloom et al., 2015). Previous studies mainly focus on the degree of industrial capital intensity and market competition to analyze the market influences on corporate behaviors.

For instance, industrial characteristics determine the way of market competition and the pattern of corporate innovative activities (Dekle, 2002; Nesta et al., 2014). Generally, the higher the degree of industry capital intensity (e.g., capital intensive industries) the greater the pressure for business enterprises to build up market competitive power through gaining and maintaining technological advantage. Technological advantages will reduce the operational risk of listed companies (Dai \& Liu, 2013). Therefore, the higher the degree of industrial capital intensity, the better the advantageous status of a business enterprise, the less the incentive for innovation investment by the enterprise, therefore, its investment in innovation project may be lower.

H2a: The industrial capital intensity is negatively associated with innovation input ( $R \& D$ investment) of a listed company.

In the segmented market with fiercer competition, there are more market participants, and the average profit margin is lower in the market segment, so as the lower market prices and business profitability for the participating companies (Markides \& Geroski, 2004; Ping \& Zhou, 2007; Turner et al., 2010). Thus the investment in innovation would be relatively less. However, in the industries with higher market-entrance thresholds, competition is relatively lower with 
fewer market participants, so their market prices and profitability are higher, as the participating companies, comparing to the counterparts with lower industrial capital intensity, can invest more in innovation (Park, 2015; Davis \& Orhangazi, 2020). This hypothesis is as below:

$H 2 b$ : The degree of market competition in the industrial segment is negatively correlated with the innovation input ( $R \& D$ investment) of a listed company.

\subsubsection{Government Characteristics}

Government intervention over corporate business is exercised in both direct regulation and indirect regulation from the perspective of corporate innovation investment. Offering governmental grants or innovation subsidies is a direct means to stimulate innovation behavior of business enterprises. Since the government makes appropriate planning and top-level design to enable the market to play a regulatory role, it can also indirectly influence the innovation behavior of business enterprises through the macro-control over the operation of market mechanism. The main government regulation or control variables in prior research include government subsidies and the marketization development (Hong et al., 2016).

Governmental subsidies help to share the risk of corporate innovation activities (Czarnitzki \& Hussinger, 2004). Business enterprises make investment in innovation with governmental subsidies can reduce innovation risk and enhance the success rate of innovation, thereby promoting enterprises to increase their investment in innovation (Li, 2011; Grossi et al., 2015). Governmental subsidies to corporate innovation investment are an important part of the governmental subsidies in China. In 2018, government subsidies for innovation projects reached a total of RMB 152.738 billion in the country, and $97.6 \%$ of A-share listed companies have received certain governmental subsidies. For instance, the average governmental innovation subsidies in our sample companies are of RMB 2.11 million. It is necessary to consider the effect of governmental subsidies on corporate innovation investment behavior, therefore:

H3a: Innovation input ( $R \& D$ investment) by a listed company is positively correlated with governmental innovation subsidies.

A high degree of marketization development means less government's direct intervention and business enterprises can operate more independently and compete fairly in the market, and the high risks and externalities of innovation output have to be borne by themselves. With the alternation of government regulatory means and functions, and the continuous progress of economic decentralization and deregulation in the market, China has rapidly transformed towards a market economy over the last two decades. However, due to the unbalance in economic development across regions in the country, it is expected that the degree of marketization in different geographical regions remain varied to a certain extent, which may have an impact on corporate innovation behaviors although such as an impact should diminish with the growth of market economy in China (Sun et al., 2017; Graaff et al., 2020). In the regions with higher degree 
of marketization development, intensified market competition prompt business enterprises to have more investment in innovation. This can be another hypothesis in regard of governmental influence:

$H 3 b$ : There is a positive relationship between the level of regional marketization development and the innovation input ( $R \& D$ investment) of a listed company.

\subsection{Regression Model}

The above hypotheses are developed based on the theoretical framework for corporate innovation input decision-making as constructed aforementioned. We select a sample of Chinese listed company for empirical analysis, which is not only conducive to test the efficacy of the innovation input decision-making model, but also enable to overcome the problem of lacking theoretical justification for corporate innovation investment and of inconsistent findings due to missing variable problem. Differentiated from prior research, we intend to incorporate the influential factors from the three perspectives (i.e., firm, government and market) in the observation simultaneously, while taking year, industry and other variables to control for their particularity on corporate innovation behaviors. We adapt the commonly used analytical model to examine the impact of various influential factors on innovation input ( $R \& D$ investment) by the Chinese listed companies in this study. The general format of the regression model is as indicated in Equation (13).

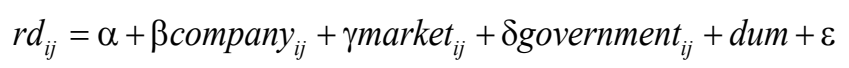

The dependent variable $R d$ represents corporate innovation input (R\&D investment), Company denotes firm-specific characteristics factors, Market represents industry-specific or market factors, and Government denotes governmental behavior factors. The subscript $i$ denotes enterprise and $j$ represents the observation year. dum is a dummy variable taking the company/year, and industry/year respectively, to control for the industry and yearly effect accordingly.

\section{Data and Variables}

\subsection{Data Source and Variable Definition}

We collect data from the 2008-2015 annual reports of the A-share listed companies, various statistical yearbooks, marketization indexes and other sources in China. ${ }^{3}$ The listed company data are collected from the Guotaian database, a main market database covering all listed firms in China and it is widely used in market-related empirical research in the country. We use text analysis research method to screen and find the information about governmental subsidies in the footnotes to annual financial statements of the listed companies to collect go${ }^{3}$ The study period is set mainly due to the considerations of: 1) the Chinese government has introduced a new set of Accounting Standards for Business Enterprises (2016) that modifies the accounting treatment for R\&D spending substantially; and 2) the availability of the regional marketization index published in 2016 (Wang et al., 2017b). 
vernmental innovation subsidies data. Industry or market data are collected through the annual statistical reports compiled by the National Bureau of Statistics of China for various industries, including manufacturing, transportation, telecommunication, hotels and catering, wholesale and retail, construction, and real estate industry, and supplemented by the industrial statistical yearbooks. Following Shen and Zou (2018), the marketization index and the government-market relationship index ${ }^{4}$ are adopted from the "Report on China's Marketization Index by Provinces (2016)" compiled by Wang et al. (2017b). ${ }^{5}$ Data sorting is performed and companies with missing data, with ST status, ${ }^{6}$ and with no expenditure on innovation project (R\&D spending) are deleted. Finally, a set of panel data with a total of 9856 firm-year observations of the Chinese listed companies from 2008 to 2015 is obtained.

The innovation input (R\&D investment) (Inrd) of the sample listed companies is expressed in terms of the total amount of R\&D investment, taking the logarithm form.

Firm size (size) is usually expressed by total assets or the number of employees in prior research (Kim et al., 2014; Yang \& Yu, 2018), so total assets at year-end are used in this study. Firm profitability ( $p r f)$ can be represented in terms of net profit or operating profit margin. Considering that net profit is affected by firm size and non-operating profit, we use operating profit margin to denote a firm's profitability. The financial leverage (Ir) is often expressed as the debt ratio, and we use asset-liability ratio at the yearend. Firm age is measured as the actual number of years from their establishment date to the study year of the sample listed companies. The nature of equity ownership (i.e., type of enterprise property rights) (nat) is represented by a dummy corresponding to SOEs, privately-run enterprises (PREs), foreign-invested enterprises (FIEs), and others.

The industrial capital intensity (fin) is used to denote the level of market segmentation or intensity of industrial competition and we adopt the ratio of total capital/assets of the industry over total number of employees in the industrial segment. In addition, the commonly used industrial concentration measure or Herfindahl index indicates the market dominance of large companies (proxy for industrial competition intensity) although there is a lack of consensus on this regard (Chen et al., 2018). Following prior research, we use the number of market participants and the average profit ratio of the industry to measure the degree of market competition as a proxy for the market effect on corporate innovation behaviors (Kock \& Gemunden, 2016). More market participants in the ${ }^{4}$ The marketization development index (by province) is an aggregated index with five dimensions of measurements, compiled and published by Chinese economists (Wang et al., 2017b). However the government-market relation index is a subset of the marketization index, especially to measure the governmental regulation on market development.

${ }^{5}$ The data for 2015 are supplemented by taking trend analysis.

${ }^{6} \mathrm{ST}$ denotes to "Special Treatment" for those listed companies who have reported operating losses in two consecutive periods, or their equity capital is less than their net assets, or receiving denial auditor opinion on their financial statements, and who will subject to the restrictive trading rules set by The Chinese Regulatory Commission for Securities Market. Thus it is an indicator of financial abnormity for the "ST" companies. 
segmented market mean greater pressure and motivating force for market competition. Higher average operating profit margin in the industrial market implies less competition in the segmented industrial market (Crowley \& Bourke, 2018; Li \& Yang, 2019). We take the logarithm of total number of market participants (num) and the industrial average operating profit margin (apr) alternatively to enhance data robustness for market-specific variables.

The logarithms of the governmental subsidies to corporate innovation projects in current period $(g b u)$ and the governmental innovation subsidies in prior period $(p g b)$ are used to measure the effect of direct governmental regulation on corporate innovation input activities, while data for the two periods are compared to enhance the robustness.

Following Zuo et al. (2016) and Shen and Zou (2018), we adopt the regional marketization index, including the aggregated marketization development index (mar) and the government-market relationship index (gam) to proxy, alternatively, for indirect government regulation effect accordingly.

The definition and measurement of dependent variable, independent variables and control variables in this study are specified in Table 1.

\subsection{Descriptive Statistics and Correlation Analysis}

To alleviate the outliner effect, data of innovation investment (R\&D spending), governmental subsidies, and operating profit margin of the sample listed companies are winsorized at the $1 \%$. The descriptive statistics of the main variables in this study are shown in Table 2.

As indicated in Table 2, the average total assets of the sample listed companies are $\mathrm{RMB} 2.5$ billion $\left(=\mathrm{e}^{12.43} / 10,000\right)$, which is in a relatively large scale. The average operating profit margin of the sample companies is about $8.77 \%$, close to the industrial average, but both the highest and the lowest operating profit margins of the sample companies deviate substantially from the industrial average, indicating there is a considerable variance in the operating profitability among the sample companies. The difference between the maximum and minimum industrial capital intensity is 215 times, so a great variance exists across industries. A comparison of the current- and the prior period governmental subsidies shows that both the amount and the scope of governmental subsidies to corporate innovation projects are in an increasing trend. We run the VIF test with no values greater than 10 , thus the problem of multicollinearity is remote in this study.

Table 3 shows the Spearman correlation coefficients for the main variables.

The univariate correlation coefficients for most variables are smaller than 0.5. The correlation coefficients between governmental innovation subsidies in current period $(g b u)$ and prior period $(p g b)$, marketization index (mar) and government market relationship index (gam) are greater than 0.5 . These two pairs of variables show certain correlation only exists in the between-pair, but does not appear with other variables. So long as these alternative measures of the two 
related variables are not incorporated into regression at the same time, the multicollinearity problem can be ruled out accordingly. It should be noted that the signs of the correlation coefficients of the marketization index (mar) and the government market relationship index (gam) are not completely consistent with other variables, indicating that there is certain difference between the two alternative measurements of indirect government intervention.

Table 1. Definition and measurement of main variables.

\begin{tabular}{|c|c|c|}
\hline Variable & Definition & Measurement (Unit) \\
\hline Inrd & Investment in innovation projects (R\&D) & Logarithm of R\&D investment (in RMB 10,000) \\
\hline size & Firm Size & Logarithm of total assets at year end (in RMB 10,000) \\
\hline prf & Profitability & Operating profit margin (\%) \\
\hline $\operatorname{lr}$ & Leverage (Debt ratio) & Total liabilities/Total assets (\%) \\
\hline age & Firm Age & Number of years from establishment date to the study period \\
\hline nat & Nature of equity ownership & SOEs $=0 ;$ PREs $=1$, FIEs $=2$, Others $=3$ \\
\hline fin & Market concentration by industry & Industrial total assets /Industrial total employees (RMB 100,000/person) \\
\hline num & Industrial competition intensity (participants) & Total \# of participating firms in the industrial segment \\
\hline apr & Industrial average profitability & Industrial average of operating profit margin (\%) \\
\hline$g b u$ & Governmental subsidies in current period & $\begin{array}{l}\text { Logarithm of governmental subsidies to innovation investment in current period } \\
\qquad \text { (in RMB 10,000) }\end{array}$ \\
\hline$p g b$ & Governmental subsidies in prior period & $\begin{array}{l}\text { Logarithm of governmental subsidies to innovation investment in prior period } \\
\qquad \text { (in RMB 10,000) }\end{array}$ \\
\hline mar & Level of regional marketization & Index of regional marketization (Source: Wang et al., 2017b) \\
\hline gam & Government-market relations & Index of government-market relation (Source: Wang et al., 2017b) \\
\hline
\end{tabular}

Table 2. Descriptive statistics of main variables.

\begin{tabular}{|c|c|c|c|c|c|c|}
\hline Variable & Definition & $\mathrm{N}$ & Mean & S.D. & Min. & Max. \\
\hline lnrd & Logarithm of R\&D Investment & 9856 & 8.1929 & 1.4278 & 4.2638 & 12.6427 \\
\hline size & Firm size & 9856 & 12.43 & 1.305 & 8.668 & 19.29 \\
\hline prf & Operating profit margin (\%) & 9856 & 0.0877 & 0.127 & -0.425 & 0.469 \\
\hline lr & Leverage/Debt ratio (\%) & 9856 & 0.398 & 0.206 & 0.0075 & 0.881 \\
\hline age & Firm age (year) & 9856 & 14.98 & 5.329 & 3 & 60 \\
\hline nat & Type of equity ownership & 9856 & 0.934 & 0.843 & 0 & 3 \\
\hline fin & Intensity of industrial competition (industrial employee-asset ratio) & 9856 & 10.85 & 17.45 & 0.937 & 201.6 \\
\hline num & Number of industrial participants (log) & 9856 & 9.514 & 0.834 & 4.317 & 11.45 \\
\hline apr & Average industrial profitability (\%) & 9856 & 0.0867 & 0.118 & -0.049 & 0.843 \\
\hline$g b u$ & Govent. subsidies $(t)(\log )$ & 7488 & 5.354 & 1.803 & -3.912 & 11.31 \\
\hline$p g b$ & Govent. subsidies $(t-1)(\log )$ & 7018 & 5.249 & 1.830 & -3.912 & 11.27 \\
\hline $\operatorname{mar}$ & Marketization development index & 9856 & 8.019 & 1.710 & -0.300 & 10.65 \\
\hline gam & Government-market relation index & 9856 & 7.233 & 1.522 & -6.750 & 9.650 \\
\hline
\end{tabular}


Table 3. Spearman correlation coefficients.

\begin{tabular}{|c|c|c|c|c|c|c|c|c|c|c|c|c|c|}
\hline & size & prf & $l r$ & age & nat & fin & apr & num & $g b u$ & $p g b$ & mar & gam & Inrd \\
\hline size & 1 & & & & & & & & & & & & \\
\hline prf & -0.151 & 1 & & & & & & & & & & & \\
\hline lr & 0.199 & -0.138 & 1 & & & & & & & & & & \\
\hline age & 0.484 & -0.458 & 0.158 & 1 & & & & & & & & & \\
\hline nat & -0.458 & 0.246 & -0.158 & -0.171 & 1 & & & & & & & & \\
\hline fin & 0.18 & -0.017 & 0.122 & 0.163 & -0.074 & 1 & & & & & & & \\
\hline apr & 0.07 & -0.043 & 0.084 & 0.082 & -0.071 & 0.141 & 1 & & & & & & \\
\hline num & -0.049 & -0.058 & 0.026 & 0.05 & 0.028 & 0.213 & 0.329 & 1 & & & & & \\
\hline$g b u$ & 0.398 & -0.023 & 0.083 & 0.151 & -0.154 & -0.031 & -0.056 & -0.003 & 1 & & & & \\
\hline$p g b$ & 0.391 & -0.042 & 0.09 & 0.172 & -0.172 & -0.03 & -0.045 & -0.014 & 0.614 & 1 & & & \\
\hline $\operatorname{mar}$ & -0.084 & 0.071 & 0.108 & -0.059 & 0.274 & 0.017 & -0.016 & 0.105 & 0.025 & 0.025 & 1 & & \\
\hline gam & -0.15 & 0.073 & 0.026 & -0.097 & 0.207 & -0.018 & -0.019 & 0.131 & -0.016 & -0.02 & 0.797 & 1 & \\
\hline Inrd & 0.579 & 0.007 & 0.064 & 0.206 & -0.184 & -0.089 & -0.084 & -0.007 & 0.429 & 0.407 & 0.114 & 0.039 & 1 \\
\hline
\end{tabular}

\section{Results}

\subsection{Main Test Results}

Based on the analytical model as indicated as Equation (13), the results of Hausman test for random effect and fixed effect show that the $p$-value is $<0.01$, and the residual of the explained variable has a fixed effect. Thus we run the fixed effect regressions for analysis, and the robust standard error is used. We incorporate dependent variable and the mutually exclusive independent variables into the regression models in alternative settings: 1) taking industrial average profitability (apr) or industrial competition intensity (num) alternatively to capture the effect of industrial concentration and market competition (Models 1-4 vs. Models 5-8); 2) incorporating governmental innovation subsidies received in current period $(g b u)$ or in prior period $(p g b)$ alternatively (Models 1-2 and 5-6 vs. Models 3-4 and 7-8); and 3) taking regional marketization development index (mar) or government-market relation index (gam) alternatively to proxy for indirect government intervention (Models 1, 3, 5, 7, vs. Models 2, 4, 6, 8 ). The regression results are shown in Table 4 . The industry and year dummies and sample size are incorporated in regressions. In order to check and control for the endogenity, the variables of firm-specific factors are measured with one period lag in the regressions. The coefficients are generally at the acceptable significance levels, so the regression results are robust.

From the regression results, the sign of firm size variable (size) is positive and at the $1 \%$ significance level, which supports $H 1 a$, and is consistent with that of Ren et al. (2010). Economically speaking, for every 1\% increase in the asset scale of the listed companies, the total investment in innovation ( $R \& D$ spending) will increase by about $0.5 \%$ (coefficient of 0.536 to 0.548 across Models $1-8$ ). 
Z. J. Lin et al.

Table 4. Results of regressions.

\begin{tabular}{|c|c|c|c|c|c|c|c|c|}
\hline Variable & Modl. 1 & Modl. 2 & Modl. 3 & Modl. 4 & Mol. 5 & Mod.6 & Modl.7 & Modl.8 \\
\hline \multirow{2}{*}{ size } & $0.541^{\star * *}$ & $0.543^{* * *}$ & $0.536^{* * *}$ & $0.539^{* * *}$ & $0.547^{\star * *}$ & $0.548^{\star * *}$ & $0.541^{\star * *}$ & $0.544^{\star * \star}$ \\
\hline & $(0.0521)$ & $(0.0522)$ & $(0.0554)$ & $(0.0556)$ & $(0.0513)$ & $(0.0516)$ & $(0.0549)$ & $(0.0552)$ \\
\hline \multirow{2}{*}{ prf } & $2.071^{* * *}$ & $2.085^{\star * *}$ & $1.892^{* * *}$ & $1.918^{\star * *}$ & $2.172^{\star * *}$ & $2.177^{\star * *}$ & $1.977^{\star * *}$ & $1.997^{\star * *}$ \\
\hline & $(0.424)$ & $(0.421)$ & $(0.463)$ & $(0.460)$ & $(0.420)$ & $(0.417)$ & $(0.460)$ & $(0.456)$ \\
\hline \multirow{2}{*}{$l r$} & $0.268^{* *}$ & $0.242^{\star}$ & $0.290^{* *}$ & $0.277^{\star}$ & $0.269^{* *}$ & $0.243^{*}$ & $0.292^{* *}$ & $0.278^{*}$ \\
\hline & $(0.124)$ & $(0.125)$ & $(0.142)$ & (0.143) & $(0.124)$ & $(0.125)$ & $(0.143)$ & $(0.144)$ \\
\hline \multirow{2}{*}{ age } & $0.0936^{\star * *}$ & $0.0938^{\star * *}$ & $0.0891^{\star * *}$ & $0.0928^{\star * *}$ & $0.0891^{\star * *}$ & $0.0896^{* * *}$ & $0.0855^{\star * *}$ & $0.0888^{* * *}$ \\
\hline & $(0.0120)$ & $(0.0094)$ & $(0.0122)$ & $(0.0096)$ & $(0.0119)$ & $(0.0092)$ & $(0.0122)$ & $(0.0096)$ \\
\hline \multirow{2}{*}{ nat } & 0.0532 & 0.0589 & 0.113 & 0.119 & 0.0499 & 0.0556 & 0.109 & 0.115 \\
\hline & $(0.127)$ & $(0.125)$ & $(0.117)$ & $(0.115)$ & $(0.128)$ & $(0.125)$ & $(0.118)$ & $(0.116)$ \\
\hline \multirow{2}{*}{ fin } & $-0.0083^{* * *}$ & $-0.0085^{\star * *}$ & $-0.0079^{\star *}$ & $-0.0081^{\star *}$ & $-0.0071^{\star *}$ & $-0.0075^{\star *}$ & $-0.0072^{\star *}$ & $-0.0075^{\star *}$ \\
\hline & $(0.0030)$ & $(0.0030)$ & $(0.0034)$ & $(0.0034)$ & $(0.0030)$ & $(0.0030)$ & $(0.0034)$ & $(0.0034)$ \\
\hline \multirow{2}{*}{ apr } & $2.430^{\star * *}$ & $2.281^{\star * *}$ & $2.238^{\star * *}$ & $2.084^{\star * \star}$ & & & & \\
\hline & $(0.746)$ & $(0.734)$ & $(0.717)$ & $(0.702)$ & & & & \\
\hline \multirow{2}{*}{ num } & & & & & $-0.145^{\star * *}$ & $-0.125^{\star * *}$ & $-0.103^{\star *}$ & $-0.0857^{\star}$ \\
\hline & & & & & $(0.0439)$ & $(0.0434)$ & $(0.0486)$ & $(0.0483)$ \\
\hline \multirow{2}{*}{$g b u$} & $0.0279^{* * *}$ & $0.0273^{\star * *}$ & & & $0.0273^{* * *}$ & $0.0268^{* * *}$ & & \\
\hline & $(0.0069)$ & $(0.0069)$ & & & $(0.0068)$ & $(0.0068)$ & & \\
\hline \multirow{2}{*}{$p g b$} & & & $0.0124^{*}$ & $0.0115^{*}$ & & & $0.0124^{\star}$ & $0.0116^{*}$ \\
\hline & & & $(0.0066)$ & $(0.0066)$ & & & $(0.0066)$ & $(0.0065)$ \\
\hline \multirow{2}{*}{$\operatorname{mar}$} & 0.0023 & & 0.0108 & & 0.0023 & & 0.0089 & \\
\hline & $(0.0270)$ & & $(0.0278)$ & & $(0.0271)$ & & $(0.0278)$ & \\
\hline \multirow{2}{*}{ gam } & & $-0.0729^{* * *}$ & & $-0.0709^{* * *}$ & & $-0.0700^{* * *}$ & & $-0.0700^{\star * *}$ \\
\hline & & $(0.0169)$ & & $(0.0170)$ & & $(0.0170)$ & & $(0.0171)$ \\
\hline \multirow{2}{*}{ Const. } & $-0.447^{\star}$ & $0.0885^{*}$ & $-0.326^{*}$ & $0.190^{* *}$ & $1.127^{\star *}$ & $1.442^{* \star}$ & $0.846^{* *}$ & $1.176^{\star *}$ \\
\hline & $(0.551)$ & $(0.557)$ & $(0.596)$ & $(0.596)$ & $(0.688)$ & $(0.697)$ & $(0.762)$ & $(0.766)$ \\
\hline$N$ & 7488 & 7488 & 7018 & 7018 & 7488 & 7488 & 7018 & 7018 \\
\hline$R^{2}$ & 0.294 & 0.298 & 0.265 & 0.269 & 0.294 & 0.298 & 0.265 & 0.268 \\
\hline$N$ & 1881 & 1881 & 1845 & 1845 & 1881 & 1881 & 1845 & 1845 \\
\hline Indu. fixed & YES & YES & YES & YES & YES & YES & YES & YES \\
\hline Year fixed & YES & YES & YES & YES & YES & YES & YES & YES \\
\hline
\end{tabular}

Notes: 1) Models 1-4 incorporate industrial average profitability (apr) while Models 5-8 take industrial capital intensity (num) to capture the effect of market competition and industrial concentration alternatively. Models 1-2 and 5-6 incorporate the current-period governmental innovation subsidies (gbu) while the prior-period governmental innovation subsidies ( $\mathrm{pgb}$ ) are included in Models 3-4 and 7-8. In Models 1, 3, 5, 7, regional marketization index ( $m a r$ ) is taken while government-market relation index ( $\mathrm{gam}$ ) is used in Models 2, 4, 6, 8 to proxy for indirect government intervention. 4 ) Due to a few firms without the prior-period governmental innovation subsidies data, the total observations are 7108 , contracting to 7488 in term of the current-period governmental innovation subsidies data. 5) The significance levels are denoted as, ${ }^{\star} 10 \%$; ${ }^{* *} 5 \%$; and ${ }^{* *} 1 \%$ respectively. 
The coefficient of corporate operating profit margin variable ( $p r f)$ is positive and significant at the $1 \%$ level, which confirms $H 1 b$, i.e., there is a positive association between profitability and innovation input ( $R \& D$ investment) of the sample listed companies. With improvement in the profitability, innovation investment can increase. But the intensity of innovation investment in the sample companies is declining. More specifically, for each $1 \%$ increase in a firm's operating profit margin, the total innovation investment will increase by about $2 \%$ (coefficient of 1.892 to 2.085 across Models 1-8), but the proportion of innovation investment (R\&D spending) in its operating revenue will however decrease.

The coefficient for the leverage variable of debt ratio $(I r)$ is positive and significant at the $1 \%$ level, and the value of the coefficient in all regression models is about 0.2 to 0.3 , which supports $H 1 c$. Within a certain range, the higher the leverage (i.e., debt ratio), the more reasonable the capital structure, so there is an increase in innovation investment (R\&D spending) by the sample companies. It can be inferred that, in general, with each $1 \%$ increase in debt ratio, the total investment in innovation will increase by $0.2 \%-0.3 \%$.

The coefficient for firm age variable (age) is positive and significant at the $1 \%$ significance level, which supports $H \boldsymbol{l} d$. It shows that the R\&D investment in corporate innovation increases with the age of sample listed companies, which is consistent with the findings of Shen and Zou (2018). It can be inferred that, for one year increase in firm age, the investment in innovation will increase close to about $0.1 \%$ in general.

The coefficient of the nature of equity ownership variable (i.e., type of property rights) (nat) is positive, but not significant at the conventional level, even we change the partition rules for the equity ownership dummy, the regression results are still not significant, thus, $H \mathbf{e}$ is not supported. This finding deviates from the main view of earlier studies. It may be interpreted that with the continuous development of capital market, the improvement of corporate governance and the extension of SOEs reforms in China, the nature of equity ownership has no longer a significant impact on innovation investment behaviors of the Chinese listed companies. It could be further inferred that all market participants, regardless of equity ownership nature, must now make innovation investment to be able to survive and growth in the market.

The coefficient for the market segment characteristic variable (fin) is negative in all regression Models and significant at the $1 \%$ or the $5 \%$ levels respectively, which supports $H \mathbf{H}$ a. The higher the capital intensity in the industrial segment (i.e., with higher market entrance thresholds or less competition within the market segment), the more obvious advantage in the existing technologies and the lower the innovation risk for the sample companies. Therefore, the optimal corporate innovation investment ( $R \& D$ spending) declines relatively for the market segment with a high capital intensity. This is consistent with Wang (2015). Judging by the regression coefficients, it could be inferred that when the capital intensity of the industry in which a listed company is belonged to increases by RMB 100,000 per employee, its investment in innovation (R\&D 
spending) may decrease by about $0.007 \%-0.008 \%$.

The coefficients for the variable of the degree of competition in the market segments, in terms of the average industrial operating profit margin (apr) or the number of participating industrial enterprises (num) alternatively, are at the acceptable significance levels (i.e., $1 \%, 5 \%$ or $10 \%$ ) respectively, and the signs of the two coefficients are opposite and consistent with the expectation, which support $H 2 \boldsymbol{b}$. The greater the average industrial operating profit margin (apr), the higher the product price or the lower the product cost, so the listed companies are more willing to increase investment in innovation ( $R \& D$ spending). Accordingly, for every $1 \%$ increase in the average industrial operating profit margin, the innovation investment may increase by about $2 \%$ by the sample listed companies (coefficient of 2.084 to 2.430 across Models 1-4). On the other hand, the greater the number of participating companies in the segmented industry (num), the lower the product price and the profit margin, and the less the innovation investment ( $R \& D$ spending), which may suggest that with every 2.7 (one unit of loge) increase in the number of market participants, the innovation investment may be reduced by about $1 \%$ by the listed companies (coefficient of -0.145 to -0.085 ) across Models 5-8) in this sample.

Coefficients for the current-period governmental subsidies $(g b u)$ and the prior period governmental subsidies $(p g b)$ are significant at $1 \%$ and $10 \%$ respectively, so $\mathrm{H2a}$ is confirmed, suggesting that governmental innovation subsidies in general promote corporate innovation investment ( $R \& D$ spending), although the governmental subsidies received in current period has a more significant effect.

The coefficient of the regional marketization index (mar) is positive, but not at the conventional significance level, indicating that the level of marketization development does not have a significant effect on the innovation investment by business enterprises in China at present, which deviates from prior research that suggests the increase in marketization level is helpful to promote corporate innovation activities (Wu, 2012; Zuo et al., 2016). The coefficient of the government-market relationship variable ( $\mathrm{gam}$ ) is negative at the $1 \%$ significance level, indicating that the government-market relationship is negatively correlated with corporate innovation input ( $R \& D$ investment), which is a new and important finding of this study.

The results aforementioned are generally consistent with the inferences of the theoretical framework for corporate innovation input decision-making we have constructed based the Cournot game theory in this study, suggesting that this theoretical framework is valid and applicable to business innovation practices in China. Our empirical results are also consistent with the mainstream viewpoints of prior research, which can help to clarify the contradictory findings and build up consensus on corporate innovation input decision making research.

\subsection{Additional Test and Discussion}

Our empirical results reveal that the nature of equity ownership (i.e., types of 
corporate property rights) (nat) and the development level of regional marketization in China (mar) do not have a significant impact on the innovation input ( $R \& D$ investment) of the sample listed companies, which is a different finding in comparison of the prior research. We perform alternative tests by changing the measurement of the proxy variable of the nature of equity ownership (i.e., by the equity ownership of ultimate owner) and the coefficient remains insignificant. Thus we may infer that the marketization process in China has grown into a mature stage even its development is unbalanced across regions in the country. In particular, the regulatory and surveillance systems for Chinese capital market have improved substantially in the recent two decades. The market regulatory authorities have made great efforts to improve corporate governance of the listed companies. Furthermore, the SOEs reforms have extended into a deepened scope, as SOEs are pushed to directly undertake market pressure and risk, and to fully compete with other market participants for survival and growth. SOEs could no longer grow with governmental protection and patronage but have to rely upon self-capabilities to drive business growth. As a result, SOEs and non-SOEs should now equally pay attention to strengthen innovation capability. Under such a new business environment, the nature of equity ownership (types of enterprise property rights) should no longer be a significant factor to corporate motivation to make innovation investment. We also rerun the regression with the sub-indices of the regional marketization development index separately. The results, except for the government-market relationship index (gam), are still not significant. Thus, this finding and its inference on the effect of equity ownership is robust.

Among the five indicators of the government-market relationship index as constructed by Wang et al. (2017b), three are relevant to publicly listed companies, including the proportion of economic resources distribution through the market, the decrease of government intervention in business operations, and the reduction of non-tax burden of business enterprises. The proportion of economic resources allocated by the market is represented as the ratio of the public fiscal expenditure to the GDP. A decrease in the proportion of public fiscal expenditure over GDP may reduce governmental subsidies to corporate innovation activities. In light of $\mathbf{H 2}$ a, this will lead to a decrease in corporate innovation investment. However, with a decrease of governmental intervention, business enterprises with capital advantages can become a "quick pillager" to grasp the innovative outcomes of other enterprises through business mergers and acquisitions (Zuo et al., 2016). This potential gain is generally not reflected in the output factors underlying innovation input (R\&D investment) decisions, but could be realized by firms with technological advantages and greater competitive power, so their corresponding innovation input (R\&D investment) might be relatively reduced (a negative relationship). As publicly listed companies, they have received more public attention on their fiscal burden (taxes and fees levied by government authorities) comparing to non-listed companies. Thus the deduction of non-tax burden has relatively a smaller impact on the investment beha- 
viors of the listed companies. ${ }^{7}$

Therefore, the effect of the nature of equity ownership has become insignificant while the level of regional marketization development due to the adjustment of government-market relationship would have no direct impact on corporate innovation investment decisions. The results could provide an evidence that the Chinese economy is now with a market-oriented status, in which all market participants should pay equal attention to innovation efforts for business growth, in the perspective of corporate innovation investment decision-making. Particularly, the centralized planning and direct intervention of business innovation input decisions by government authorities have vanished, as well as the governmental patronage of SOEs has faded away. In other words, the status of a market economy has been in place in China, as all business enterprises should now invest in innovation activities to gain competitive power or advantages.

\section{Conclusion}

Corporate innovation input decision making is subject to the influence of many factors, including the price and cost of product, operating profitability, the risk and efficacy (success) of innovation projects, the cost of capital for innovation investment, the demand function, and the market and government regulations. Although varied theories and analytical models have been developed in the analyses in earlier studies, there are drawbacks in the research methods and of the omitted or missing variable problems, so the findings of previous studies are inconsistent. We therefore conduct a theoretical deduction to determine the key influential factors for corporate innovation input decisions based on Cournot game theory, incorporating multi-dimensional factors from the perspectives of firm, government and market simultaneously. We select a sample of the Chinese listed company to empirically examine the validity and efficacy of the theoretical framework that has been developed. The results of this study confirm that our analytical framework is applicable to more fully examine corporate innovation input decision making in light of $\mathrm{R} \& \mathrm{D}$ investment by business enterprises, and can help clarify the inconsistency of the findings in previous studies.

Different from prior research, we have found that, through both theoretical deduction and empirical analysis, the nature of equity ownership (types of equity property rights) and the regional marketization level in China do not have a significant impact on corporate innovation investment for the listed companies at present. The results could be interpreted that there is a very positive progress in economic reforms as the Chinese government has made concrete efforts to promote continuous adjustment of the relationship between governments and the market, followed by the substantial improvement of capital market operation, the continuous improvement of corporate governance for listed companies,

${ }^{7}$ Local government authorities have imposed varied non-tax fees on business enterprises within their jurisdictions. However, the central government has introduced the uniform tax systems and restricted the levy of non-tax fees by local authorities as an effort to stimulate business growth in the course of deepening reforms for SOEs since the mid 2010s. 
and the continuous extension of SOEs reforms to transform them to be independent market players. Equal treatment and fair competition for all business enterprises regardless of their equity ownership difference and geographical location have been incorporated in the governmental economic control on market regulation. As a result, the gap in the magnitude of marketization development across the country is diminishing, not longer to be a factor influencing corporate behaviors, especially judging from the perspective of corporate innovation input ( $R \& D$ investment) decisions. All of these may imply that the market economy status is almost in shape in China although economic reforms should be further promoted towards a fully-operated market economy in the country.

Our analysis of the influential factors for corporate innovation input decisions is based on a theoretical deduction in light of the Cournot game theoretical framework, with an expanded multi-industries sample, and more firm/year observation data are used in our empirical analysis in comparison with that in prior research. Thus, the study findings should be more robust and have broader implications for both theoretical research and business practice of corporate innovation input decision making.

Nonetheless, this study focuses mainly on the influencing factors that have been adopted, though separately, in the extant research, and does not consider the factors that are lack of standardized quantitative measurement at the time being, such as the characteristics of enterprise managers and employees, the windfall gain of innovation obtained through business mergers and acquisitions in the market, and corporate culture or business life cycle stage. Future study could be carried out to have a more thorough examination of all relevant factors underlying corporate innovation input decision making, and of the efficiency and effectiveness of corporate innovation behaviors with more sophisticated and appropriate research instruments and data when they are available.

\section{Acknowledgements}

Financial support from National Natural Science Foundation of China (Project \# 71472127) is acknowledged. The authors are grateful to the insightful comments from anonymous reviewer on previous version of this manuscript, and the encouragement and support by Journal editors are appreciated.

\section{Conflicts of Interest}

The authors declare no conflicts of interest regarding the publication of this paper.

\section{References}

Aghion, P., Vloom, N., Blundell, R., Griffith, R., \& Howitt, P. (2005). Competition and Innovation: An Inverted-U Relationship. The Quarterly Journal of Economics, 120, 701-728. https://doi.org/10.1093/qje/120.2.701

Allen, R., \& Helms, M. M. (2006). Linking Strategic Practices and Organizational Performance to Porter's Generic Strategies. Business Process Management Journal, 12, 433-454. 
https://doi.org/10.1108/14637150610678069

Almus, M., \& Czarnitzki, D. (2003). The Effects of Public R\&D Subsidies on Firms' Innovation Activities: The Case of Eastern Germany. Journal of Business Economics Statistics, 21, 226-236. https://doi.org/10.1198/073500103288618918

Amir, R. (1996). Cournot Oligopoly and the Theory of Supermodular Games. Games and Economic Behavior, 15, 132-148. https://doi.org/10.1006/game.1996.0062

Antonelli, C. (2006). A Failure-Inducement Model of Research and Development Expenditure: Italian Evidence from the Early 1980s. Journal of Economic Behavior \& Organization, 12, 159-180. https://doi.org/10.1016/0167-2681(89)90053-X

Audretsch, A. D. B. (1988). Innovation in Large and Small Firms: An Empirical Analysis. The American Economic Review, 78, 678-690.

Baker, H. K., Dutta, S., \& Saadi, S. (2011). Management Views on Real Options in Capital Budgeting. Journal of Applied Finance, 21, 18-29.

Barasa, L., Vermeulen, P., Knoben, J., Kinyanjui, B., \& Kimuyu, P. (2019). Innovation Inputs and Efficiency: Manufacturing Firms in Sub-Saharan Africa. European Journal of Innovation Management, 22, 59-83. https://doi.org/10.1108/EJIM-11-2017-0176

Bloom, N., Propper, C., Seiler, S., \& Van Reenen, J. (2015). The Impact of Competition on Management Quality: Evidence from Public Hospitals. The Review of Economic Studies, 82, 457-489. https://doi.org/10.1093/restud/rdu045

Blundell, R., Griffith, R., \& Van Reenen, J. (2010). Market Share, Market Value and Innovation in a Panel of British Manufacturing Firms. The Review of Economic Studies, 66, 529-554. https://doi.org/10.1111/1467-937X.00097

Cai, Z., Wang, Y. Q., \& Hou, A. Y. (2013). The Relationship between Corporate Innovation Strategy and Capital Structure: An Empirical Study Based on Listed Companies in China's Chemical Industry. Technology Economics, 32, 39-43, 54. (In Chinese)

Campos, F. A., Villar, J., \& Barquin, J. (2005). Application of Possibility Theory to Robust Cournot Equilibrium in the Electricity Market. Probability in the Engineering and Informational Sciences, 19, 519-531. https://doi.org/10.1017/S0269964805050345

Carlsson, C., Fuller, R. Heikkila, M., \& Majlender, P. (2007). A Fuzzy Approach to R\&D Project Portfolio Selection. International Journal of Approximate Reasoning, 44, 93-105. https://doi.org/10.1016/j.ijar.2006.07.003

Chang, S. H., Li, Y., \& Gao, F. L. (2016). The Impact of Delaying an Investment Decision on R\&D Projects in Real Option Game. Chaos, Solitons \& Fractals, 87, 182-189. https://doi.org/10.1016/j.chaos.2016.03.035

Chen, Q., \& Lin, F. J. (2019). A Dynamic Game Model for Firm's Decision-Making of Innovation Input and Yield Based on Choice of Competitive Strategies. Journal of Management Engineering/Engineering Management, 33, 193-204. (In Chinese) https://doi.org/10.13587/j.cnki.jieem.2019.04.023

Chen, S. Y., Zhang, Q., Wang, G., Zhu, L. J., \& Li, Y. (2018). Investment Strategy for Underground Gas Storage Facilities Based on Real Option Model Considering Gas Market Reform in China. Energy Economics, 70, 132-142. https://doi.org/10.1016/j.eneco.2017.12.034

Chen, Z. C., \& Yu, X. (2007). Research on the External Environmental Influencing Factors of Enterprise R\&D Investment: Based on Industry-Level Panel Data Analysis. Scientific Research Management, No. 2, 78-84. (In Chinese)

Cheng, L. W., \& Dai, X. Y. (2012). Analysis of R\&D Investment Distribution Characteristics and R\&D Investment Intensity Influencing Factors. China Soft Sciences, No. 8, 152-165. (In Chinese) 
Crespi, G. P., Radi, D., \& Rocca, M. (2017). Robust Games: Theory and Application to a Cournot Duopoly Model. Decisions in Economics and Finance, 40, 177-198. https://doi.org/10.1007/s10203-017-0199-3

Crowley, F., \& Bourke, J. (2018). The Influence of the Manager on Firm Innovation in Emerging Economies. International Journal of Innovation Management, 22, Article ID: 1850028. https://doi.org/10.1142/S1363919618500287

Czarnitzki, D., \& Hussinger, K. (2004). The Link between R\&D Subsidies, R\&D Spending and Technological Performance. ZEW-Centre for European Economic Research Discussion Paper No. 04-056. https://doi.org/10.2139/ssrn.575362

Dai, K. Z., \& Liu, Y. J. (2013). Industry Marketization Process and Innovation Performance: Empirical Analysis of China's High-Tech Industry. Quantitative Economics and Technical Economics Research, 30, 37-54. (In Chinese)

Davis, L., \& Orhangazi, Ö. (2020). Competition and Monopoly in the U. S. Economy: What Do the Industrial Concentration Data Show? Competition \& Change, 25, 3-30. https://doi.org/10.1177/1024529420934011

Dekle, R. (2002). Industrial Concentration and Regional Growth: Evidence from the Prefectures. The Review of Economics and Statistics, 84, 310-315. https://doi.org/10.1162/003465302317411550

Denison, C. A., Farrell, A. M., \& Jackson, K. E. (2012). Managers' Incorporation of the Value of Real Options into Their Long-Term Investment Decisions: An Experimental Investigation. Contemporary Accounting Research, 29, 590-620. https://doi.org/10.1111/j.1911-3846.2011.01116.x

Dhingra, A. K., \& Moskowitz, H. (1991). Application of Fuzzy Theories to Multiple Objective Decision Making in System Design. European Journal of Operational Research, 53, 348-361. https://doi.org/10.1016/0377-2217(91)90068-7

Diéguez-Soto, J., Manzaneque, M., \& Rojo-Ramírez, A. A. (2016). Technological Innovation Inputs, Outputs, and Performance: The Moderating Role of Family Involvement in Management. Family Business Review, 29, 327-346. https://doi.org/10.1177/0894486516646917

Fan, G., Wang, X. L., \& Ma, G. G. (2011). The Contribution of China's Marketization Process to Economic Growth. Economics Research, 46, 4-16. (In Chinese)

Fu, Y. P., Rui, M. J., \& Ma, Y. (2016). Research and Development Investment, Foreign Direct Investment and Enterprise Innovation. Exploration of Economic Issues, No. 6, 28-33. (In Chinese)

Gao, G. K., Ma, S. Y., \& Zhou, M. (2017). Firm Size, Market Concentration and Innovation Performance: Empirical Evidence of A-Share Manufacturing Companies. China Forest Economics, 146, 6-9, 19.

Garg, H., \& Kumar, K. (2018). An Advanced Study on the Similarity Measures of Intuitionistic Fuzzy Sets Based on the Set Pair Analysis Theory and Their Application in Decision Making. Soft Computing, 22, 4959-4970. https://doi.org/10.1007/s00500-018-3202-1

Graaff, N., Brink, T., \& Parmar, I. (2020). China's Rise in a Liberal World Order in Transition. Review of International Political Economy, 27, 191-207. https://doi.org/10.1080/09692290.2019.1709880

Grossi, G., Papenfuß, U., \& Tremblay, M. S. (2015). Corporate Governance and Accountability of State-Owned Enterprises: Relevance for Science and Society and Interdisciplinary Research Perspectives. International Journal of Public Sector Management, 28, 274-285. https://doi.org/10.1108/IJPSM-09-2015-0166 
Gu, X. Y. (2015). Dynamic Investment Decision Model for R\&D Projects Based on Real Options. China Management Sciences, 23, 94-102. (In Chinese)

Hart, O. (1996). Theories of Optimal Capital Structure: A Managerial Discretion Perspective. In B. Allen (Ed.), Economics in a Changing World. International Economic Association Series (pp. 204-235). London: Palgrave Macmillan. https://doi.org/10.1007/978-1-349-25168-1_10

Hauschild, B., \& Reimsbach, D. (2015). Modeling Sequential R\&D Investments: A Binomial Compound Option Approach. Business Research, 8, 39-59. https://doi.org/10.1007/s40685-014-0017-5

Ho, S.-H., \& Liao, S.-H. (2011). A Fuzzy Real Option Approach for Investment Project Valuation. Expert Systems with Applications, 38, 15296-15302. https://doi.org/10.1016/j.eswa.2011.06.010

Hong, J., Feng, B., Wu, Y. R., \& Wang, L. B. (2016). Do Government Grants Promote Innovation Efficiency in China's High-Tech Industries? Technovation, 57-58, 4-13. https://doi.org/10.1016/j.technovation.2016.06.001

Jabeen, F., Faisal, M. N., Matroushi, H. A., \& Farouk, S. (2019). Determinants of Innovation Decisions among Emirati Female-Owned Small and Medium Enterprises. International Journal of Gender and Entrepreneurship, 11, 408-434. https://doi.org/10.1108/IJGE-02-2019-0033

Kim, K. T., Lee, D. J., \& An, D. (2020). Real Option Valuation of the R\&D Investment in Renewable Energy Considering the Effects of the Carbon Emission Trading Market: A Korean Case. Energies, 13, 622-634. https://doi.org/10.3390/en13030622

Kim, K. T., Lee, D., \& Park, S. J. (2014). Evaluation of R\&D Investments in Wind Power in Korea Using Real Option. Renewable and Sustainable Energy Reviews, 40, 335-347. https://doi.org/10.1016/j.rser.2014.07.165

Kock, A., \& Gemunden, H. G. (2016). Antecedents to Decision-Making Quality and Agility in Innovation Portfolio Management. Journal of Production Innovation Management, 33, 670-686. https://doi.org/10.1111/jpim.12336

Lee, C. Y. (2005). A New Perspective on Industry R\&D and Market Structure. Journal of Industrial Economics, 53, 101-122. https://doi.org/10.1111/j.0022-1821.2005.00247.x

Li, C. T., \& Song, M. (2010). Innovative Activities of Chinese Manufacturing Companies: The Role of Ownership and CEO Incentives. Economics Research, 45, 55-67. (In Chinese)

Li, Q., \& Zen, Y. (2009). Financial Capacity and Technological Innovation Investment Decision: A Real Option Method. Journal of Systems Engineering, 24, 1-8. (In Chinese)

Li, W. H., Bi, K., \& Ai, M. Y. (2011). The Construction of a Manufacturing Enterprise Process Innovation Decision Mode. Statistics and Decision, No. 6, 176-179 (In Chinese)

Li, X. (2011). Sources of External Technology, Absorptive Capacity, and Innovation Capability in Chinese State-Owned High-Tech Enterprises. World Development, 39, 1240-1248. https://doi.org/10.1016/j.worlddev.2010.05.011

Li, X. J., \& Yang, H. (2019). Fiscal and Tax Incentive Policies, External Environment and Corporate R\&D Investment: An Empirical Study Based on A-Share Listed Companies in China's Strategic Emerging Industries. Contemporary Finance, No. 3, 25-36. (In Chinese)

Liang, T.-P., Lin, C.-Y., \& Chen, D.-N. (2004). Effects of Electronic Commerce Models and Industrial Characteristics on Firm Performance. Industrial Management \& Data Systems, 104, 538-545. https://doi.org/10.1108/02635570410550205

Lu, C. C., \& Wang, Z. G. (2019). The Mechanism and Empirical Test of the Mismatch of 
Factor Resources and Enterprise Innovation. System Engineering Theory and Practice, 39, 1137-1153. (In Chinese)

Luo, S. D., \& Liu, C. G. (2009). Analysis of the Influencing Factors of Enterprise R\&D Investment Activities. Finance and Economics Theory and Practice, 30, 56-60. (In Chinese)

Mairesse, J., \& Mohnen, P. (2002). Accounting for Innovation and Measuring Innovativeness: An Illustrative Framework and an Application. The Economics of Technology and Innovation, 92, 226-230. https://doi.org/10.1257/000282802320189302

Markides, C. C., \& Geroski, P. A. (2004). Fast Second: How Smart Companies Bypass Radical Innovation to Enter and Dominate New Markets. IEEE Transactions on Engineering Management, 61, 196-197.

Mohanty, R. P., Agarwal, R., Choudhury, A. K., \& Tiwari, M. K. (2005). A Fuzzy ANP-Based Approach to R\&D Project Selection: A Case Study. International Journal of Production Research, 43, 5199-5216. https://doi.org/10.1080/00207540500219031

Müller, W. (2006). Allowing for Two Production Periods in the Cournot Duopoly: Experimental Evidence. Journal of Economic Behavior \& Organization, 60, 100-111. https://doi.org/10.1016/j.jebo.2004.06.025

Nakil, S. (2014). Market Concentration and Competition in OECD Mobile Telecommunications Markets. Applied Economics, 46, 3037-3048. https://doi.org/10.1080/00036846.2014.920480

Nesta, L., Vona, F., \& Nicolli, F. (2014). Environmental Policies, Competition and Innovation in Renewable Energy. Journal of Environmental Economics and Management, 67, 396-411. https://doi.org/10.1016/j.jeem.2014.01.001

Park, S. (2015). Evaluating the Efficiency and Productivity Change within Government Subsidy Recipients of a National Technology Innovation Research and Development Program. R\&D Management, 45, 549-568. https://doi.org/10.1111/radm.12097

Peltoniemi, M. (2011). Reviewing Industry Life-Cycle Theory: Avenues for Future Research. International Journal of Management Reviews, 13, 349-375. https://doi.org/10.1111/j.1468-2370.2010.00295.x

Ping, X. Q., \& Zhou, Y. (2007). The Impact of Product Market Competition on Enterprise R\&D: An Empirical Analysis of Chinese Manufacturing Industry. Industrial Economic Research, No. 5, 1-10. (In Chinese)

Ren, H. Y., Shi, P., \& Zhang, L. (2010). An Empirical Study on the Relationship between Enterprise Scale and R\&D Investment: Analysis of A-Share Manufacturing Listed Companies on the Shanghai Stock Exchange. Technological Progress and Policy, 27, 68-71. (In Chinese)

Roger, J. N. (1996). An Analysis of Deliberate and Emergent Strategies Relative to Porter's Generic Differentiator and Cost Leader: A Bias and Variance Modeling Approach. Developments in Business Simulation \& Experiential Exercises, 23, 68-73.

Schumpeter, J. A. (1951). Essays: On Entrepreneurs, Innovations, Business Cycles, and the Evolution of Capitalism. Piscataway, NJ: Transaction Publishers.

Shen, P. Y., \& Zou, H. F. (2018). Government R\&D Subsidies and Enterprise R\&D Investment: A Case Study of Chinese Manufacturing Listed Companies. Shanghai Economics Research, No. 8, 84-93. (In Chinese)

Sun, X. H., \& Li, M. S. (2014). R\&D Investment: Corporate Behavior or Industry Characteristics? Research in Sciences, 32, 724-734. (In Chinese)

Sun, X. H., Guo, X., \& Wang, Y. (2017). Government Subsidies, Nature of Ownership and Enterprise R\&D Decisions. Journal of Management Science, No. 6, 22-35. (In Chinese) 
Tan, C. Q., Liu, Z. D., Wu, D. S., \& Chen, X. H. (2018). Cournot Game with Incomplete Information Based on Rank-Dependent Utility Theory under a Fuzzy Environment. International Journal of Production Research, 56, 1789-1805. https://doi.org/10.1080/00207543.2015.1131865

Turner, S., Mitchell, W., \& Bettis, A. (2010). Responding to Rivals and Complements: How Market Concentration Shapes Generational Product Innovation Strategy. Organization Science, 21, 803-954. https://doi.org/10.1287/orsc.1090.0486

Villani, G. (2014). Valuation of R\&D Investment Opportunities with the Threat of Competitor's Entry in Real Option Analysis. Computing Economics, 43, 331-355. https://doi.org/10.1007/s10614-013-9370-2

Wang, J. M. (2015). An Empirical Analysis of the Impact of Enterprise Scale on Patent Output: Evidence of Listed Companies from 1998 to 2010. Technology Economics, 34, 29-35. (In Chinese)

Wang, N., Zhang, L. Y., \& Li, S. H. (2017a). The Impact of R\&D Investment and Market Structure on the Performance of High-Tech Enterprises. Chinese Forum on Science and Technology, 255, 72-79. (In Chinese)

Wang, W. K., \& Zhao, C. W. (2010). Research on R\&D Investment Dynamic Multi-Stage Decision Model and Its Application: Multi-Period Compound Real Options. Soft Sciences, 24, 12-16. (In Chinese)

Wang, X. L., Fan, G., \& Yu, J. W. (2017b). Report on China's Marketization Index by Provinces (2016). Beijing: National Economic Research Institute, Publishing House of Social Science Literature.

Watanabe, M. (2002). Holding Company Risk in China: A Final Step of State-Owned Enterprises Reform and an Emerging Problem of Corporate Governance. China Economic Review, 13, 373-381. https://doi.org/10.1016/S1043-951X(02)00094-9

Wu, Y. B. (2012). Which Type of Ownership Enterprise in China Is the Most Innovative? World Economy, 35, 3-29. (In Chinese)

Yang, M. Y., \& Yu, Y. (2018). Research on the Decision-Making Model of Continuous Innovation Opportunities for Innovative Enterprises. Journal of Yunnan University of Finance and Economics, 34, 96-105. (In Chinese)

Yu, S. W., Li, Z. X., Wei, Y. M., \& Liu, L. C. (2019). A Real Option Model for Geothermal Heating Investment Decision Making: Considering Carbon Trading and Resource Taxes. Energy, 189, Article ID: 116252. https://doi.org/10.1016/j.energy.2019.116252

Yuan, Y. J., \& Yang, W. (2010). The Determinants of the Continuous Innovation Ability of Private Enterprises: On the Construction of System Dynamics Model. Science and Technology Management Research, 30, 115-118. (In Chinese)

Zhang, J., Liu, Z. B., \& Zheng, J. H. (2007). Study on the Key Influencing Factors of Chinese Manufacturing Enterprises' Innovation Activities: Analysis of Jiangsu Manufacturing Enterprises Questionnaire. Management World, No. 6, 64-74. (In Chinese)

Zhang, Y., \& Zhong, S. Y. (2014). The Status Quo and Influencing Factors of R\&D Investment of the Listed Companies: Analysis of Cross-Industry Data. Chinese Forum on Science and Technology, 18, 62-65, 70. (In Chinese)

Zhao, J. (2014). Breakthrough Innovation Investment Decision Analysis Based on Real Options. Technology Economics and Management Research, No. 1, 22-26.

Zuo, J. J., Tang, Y. J., \& Ji, Z. C. (2016). Government Intervention, Market Reform and Company R\&D Innovation. Research and Development Management, 28, 80-90. (In Chinese) 